\title{
Synthesis and Characterization of Ferrate(VI) Alkali Metal by Electrochemical Method
}

\author{
Abdellatif EI Maghraoui ${ }^{1}$, Abdeleaziz Zerouale ${ }^{1}$, Mustapha Ijjaali ${ }^{1}$, Mohamed Sajieddine ${ }^{2}$ \\ ${ }^{1}$ Laboratoire de Chimie de La matière Condensée (LCMC), Faculté des Sciences et Techniques, Université Sidi \\ Mohammed Ben Abdellah, Fes, Morocco \\ ${ }^{2}$ Laboratoire de Physique et Mécanique des Matériaux, Faculté des Sciences et Techniques Beni Mellal, \\ Université Sultan Moulay Slimane, Beni Mellal, Morocco \\ Email: elmaghraabdellatif@yahoo.fr
}

Received December 27, 2012; revised February 11, 2013; accepted February 24, 2013

\begin{abstract}
This works aims at preparing at room stable $\mathrm{Na}_{2} \mathrm{FeO}_{4}$ and tracking its degradation over time. The synthetic, during this step, was carried out by electrochemical method. The latter was given maximum focus because of its simplicity and the high degree of purity of the resulting product with respect to wet and dry method. This paper reviews the development of the electrochemical method applied to the synthesis of stable at room $\mathrm{Na}_{2} \mathrm{FeO}_{4}$, optimizing the parameters impacting the performance of the oxidation of iron(II) in to iron(VI) in alkaline $\mathrm{NaOH}$, saturated at a temperature of $61^{\circ} \mathrm{C}$ and a current density of $1.4 \mathrm{~A} / \mathrm{dm}^{2}$, in order to simplify the synthesis process, to minimize the cost and to improve the production of iron(VI) to meet the growing demand of ferrate(VI) useful for water treatment. The supervision of the degradation of synthesized $\mathrm{Na}_{2} \mathrm{FeO}_{4}$ shows its stability over a period of 10 months, which makes storage and transport easier. The phases obtained were characterized by IR spectrometry, X-ray, Mössbauer, spectroscopy and thermogravimeric analysis.
\end{abstract}

Keywords: Ferrate; Bactericidal; Oxidant; Flocculants; Coagulant; Conductivity; Cathode

\section{Introduction}

Iron compounds in the oxidation state (VI) have the advantage of being powerful antioxidants and bactericides, which explains their particular interest in water treatment. Moreover, their results in reduction of ferric hydroxide, their flocculating power contributes to the elimination of organic pollutants, minerals (hydrocarbons, heavy metals, radioactive isotopes...) and industrial effluents.

The synthesis of ferrate(VI) appears to be very delicate, because of the instability that gives them their high oxidizing power. Although the existence of alkaline ferrate has been testified for a century $[1,2]$. Several efforts have been made to synthesize the solid sodium ferrate [3-7]. Difficulties were encountered in isolating the solid product from each of the resulting solutions and stabilizing it.

The $\mathrm{Na}_{2} \mathrm{FeO}_{4}$ phase was synthesized by electrochemical way. Its oxidizing power makes it possible to use it as an oxidizing agent and a disinfectant in water treatment. It first reacts as iron(VI) causing an oxidation process during which the iron(VI) is reduced to $\mathrm{Fe}(\mathrm{III})$ that is itself used in the treatment of waste water to precipitate phosphate. The induced oxidation is not accompanied by unwanted byproducts. The aim of our work is to synthe- size compounds based on iron(VI) $\mathrm{Fe}^{\mathrm{VI}} \mathrm{O}_{4}^{2-}$ stable at room temperature and replace potassium hydroxide by sodium hydroxide to obtain a significant reduction in the cost of synthesis of these ferrates. The electrochemical method used can provide a useful way for the industrial mass production of iron(VI).

\section{Experimental}

\subsection{Synthesis}

The first electrochemical synthesis of ferrate(VI) is due to Poggendorff (Poggendorff, 1841) [8]. This method is the easiest way to obtain the sodium ferrate in solution without impurities. The principle of the synthesis involves the oxidation of pig iron or iron salts in alkaline solutions using concentrated $\mathrm{NaCl}$ as a stabilizer. Figure 1 shows the experimental synthesis.

Next the various tests made by G. Grube $[9,10]$, in concentrated $\mathrm{NaOH}$ environment by varying the Current density and temperature and the electrolysis time. During these tests, we found out that the performance of the iron oxidation varies depending on the current density, the temperature and the electrolysis time, according to Figure 2. 


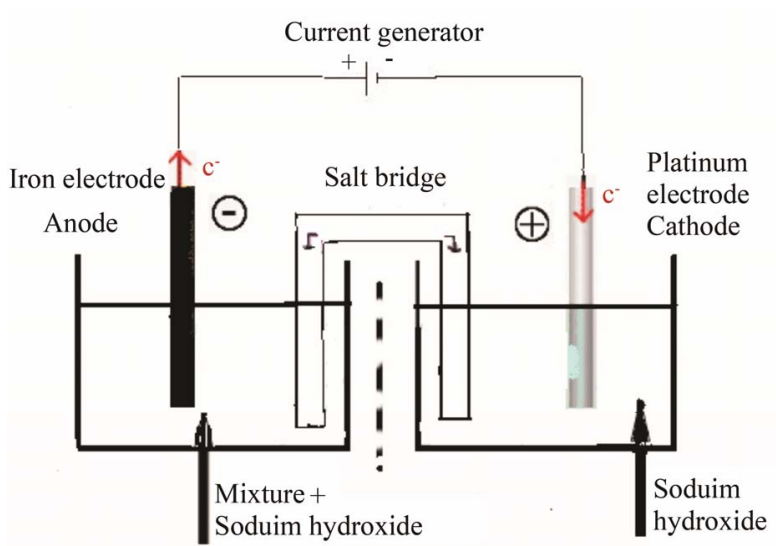

Figure 1. Schematic representation of the electrochemical cell for the synthesis of ferrate.

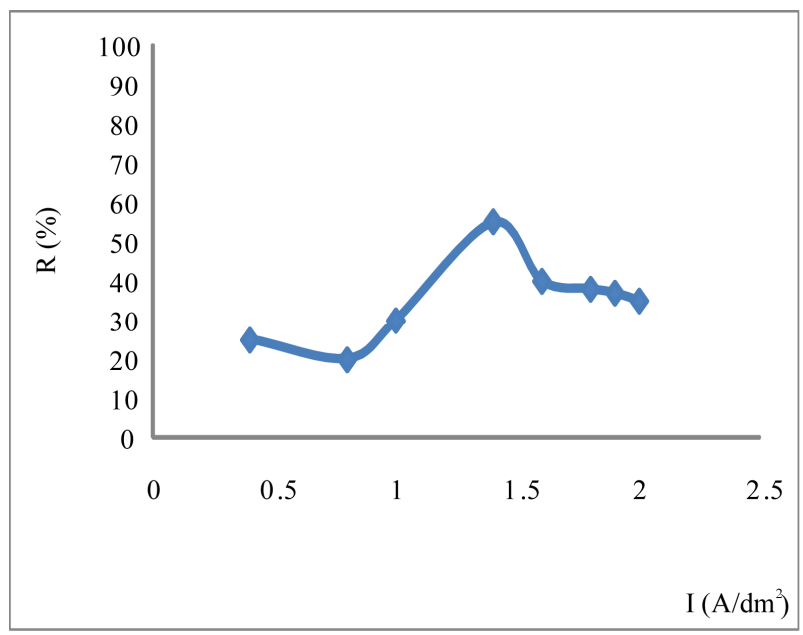

Figure 2. Performance of the oxidation of iron as a function of the current density $\mathrm{I}$ at $\mathrm{T}=61^{\circ} \mathrm{C}$ in concentrated $\mathrm{NaOH}$ for $I=1.4 \mathrm{~A} / \mathrm{dm}^{2}$. Performance reaches a maximum value of $60 \%$.

The increase in temperature leads to higher yields but with a maximum at $\mathrm{T}=61^{\circ} \mathrm{C}$ Figure 3. Indeed, it catalyzes the oxidation of iron. Regarding the electrolysis time, it is obvious, from a first abort, that the number of moles of ferrates produced will increase if the reaction time is longer. But, alongside with this, we must not forget that we operate in aqueous media and that in contact with water, ferrate is reduced to form a precipitate of ferric hydroxyl according to the reaction:

$$
2 \mathrm{Na}_{2} \mathrm{FeO}_{4}+5 \mathrm{H}_{2} \mathrm{O} \leftrightarrow 4 \mathrm{NaOH}+2 \mathrm{Fe}(\mathrm{OH})_{3}+3 / 2 \mathrm{O}_{2}
$$

In fact, from Figure 4, we can notice that beyond about an hour, the rate of decomposition $\mathrm{FeO}_{4}^{2-}$ exceeds that of synthesis, since the over all performance drops.

The reactions involved are:

Anode

Simultaneous oxidation of iron and solvent according

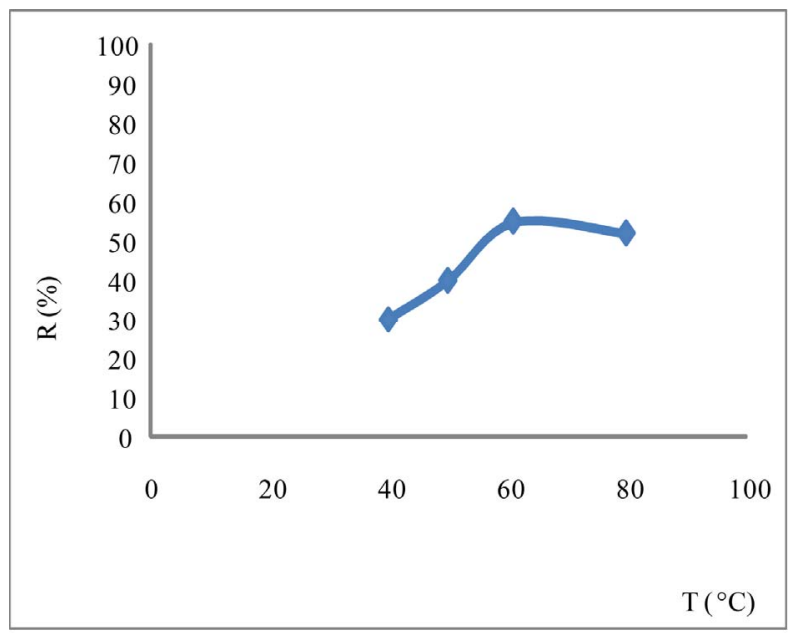

Figure 3. Yield of the oxidation of iron depending on temperature $\mathrm{T}$ in $\mathrm{NaOH}$ saturated with $\mathrm{I}=1.4 \mathrm{~A} / \mathrm{dm}^{2}$.

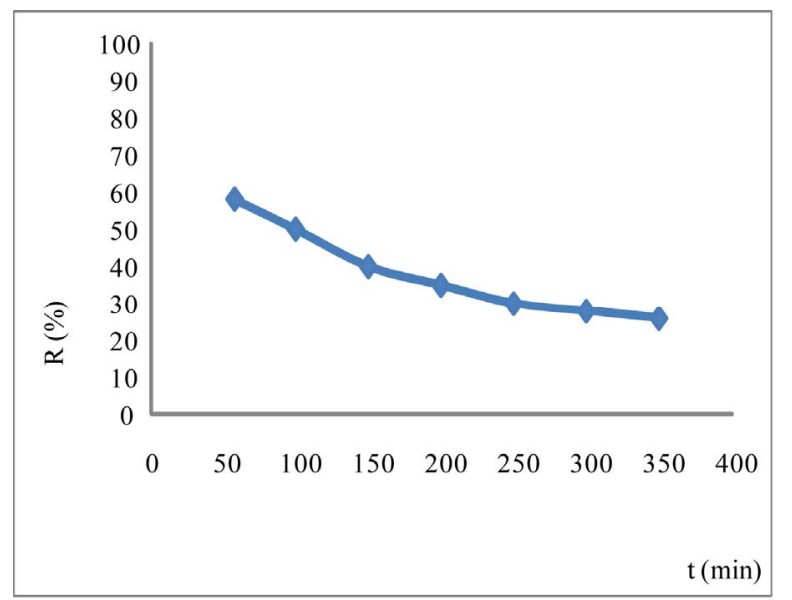

Figure 4. Effect of electrolysis time on the efficiency of the anodic oxidation of iron at $\mathrm{T}=61^{\circ} \mathrm{C}$ in concentrated $\mathrm{NaOH}$ with $I=1.4 \mathrm{~A} / \mathrm{dm}^{2}$.

to the reaction:

$$
\begin{aligned}
\mathrm{Fe}+8 \mathrm{OH}^{-} & \rightarrow \mathrm{FeO}_{4}^{2-}+4 \mathrm{H}_{2} \mathrm{O}+6 \mathrm{è} \\
4 \mathrm{OH}^{-} & \rightarrow \mathrm{O}_{2}+2 \mathrm{H}_{2} \mathrm{O}+6 \text { è }
\end{aligned}
$$

To obtain sufficiently high concentration ferrate, we use another source of $\mathrm{Fe}(\mathrm{III})$, that is the ferric salt $\mathrm{FeCl}_{3}$, $6 \mathrm{H}_{2} \mathrm{O}$ according to the following reaction:

$$
\mathrm{FeCl}_{3}+8 \mathrm{OH}^{-} \rightarrow \mathrm{FeO}_{4}^{2-}+4 \mathrm{H}_{2} \mathrm{O}+3 \mathrm{é}
$$

$\mathrm{FeO}_{4}^{2-}$ Formation process

Trivalent iron reacts with the $\mathrm{OH}^{-}$to form an oxohydroxyl complex de $\mathrm{Fe}_{\mathrm{x}} \mathrm{O}_{\mathrm{y}} \cdot \mathrm{nH}_{2} \mathrm{O}$ type which will then be oxidized electrochemically in the presence of ferrate halide $(\mathrm{NaCl})$.

Cathode held.

Only the reduction in hydrogen of the solvent was

$$
\mathrm{H}_{2} \mathrm{O}+2 \mathrm{e} \rightarrow \mathrm{H}_{2}+2 \mathrm{OH}^{-}
$$




\subsection{Characterizations}

\subsubsection{X-Ray Diffraction}

Measures by a radiation ray diffractometer $\mathrm{CuK}$ of a compound of ferrate powder $\mathrm{Na}_{2} \mathrm{FeO}_{4}$ Figure 5 proves the crystal structure of ferrate $[11,12]$ and demonstrates the existence of an isomorphism with $\mathrm{K}_{2} \mathrm{FeO}_{4}$ and $\mathrm{BaFeO}_{4}$ as found by Stuart Licht, Vera. Naschitz and collaborators [13]. From the analytical point of view, the X-ray diffraction is one of the means used to verify the presence of ferrate.

The spectrum obtained on $\mathrm{Na}_{2} \mathrm{FeO}_{4}$ bears a strong similarity with that of isomorphous compounds. There is a splitting of the lines corresponding to planes (102), (202), (013), (200), (002), (004) [14-16].

\subsubsection{Infrared Spectrum}

The appearance of an infrared spectrum is related to the symmetry of the molecule or study group. We expected for $\mathrm{FeO}_{4}^{2-}$, with tetrahedral structure, to find: first, the fundamental bands characteristic of a symmetry $2 \mathrm{~d}$ : either bands $\sqrt{3}$ and $\sqrt{4}$ from the two degenerate modes of vibration: the symmetric stretching and angular deformation within the tetrahedron resulting in inactive modes in infrared absorption, bands $\sqrt{1}$ and $\sqrt{2}$ must be absent from the spectra [17]. On the other hand, a similarity is among infrared spectra of isomorphism series [18]. The presence of a band $\sqrt{1}$ and a triplet for $\sqrt{3}$

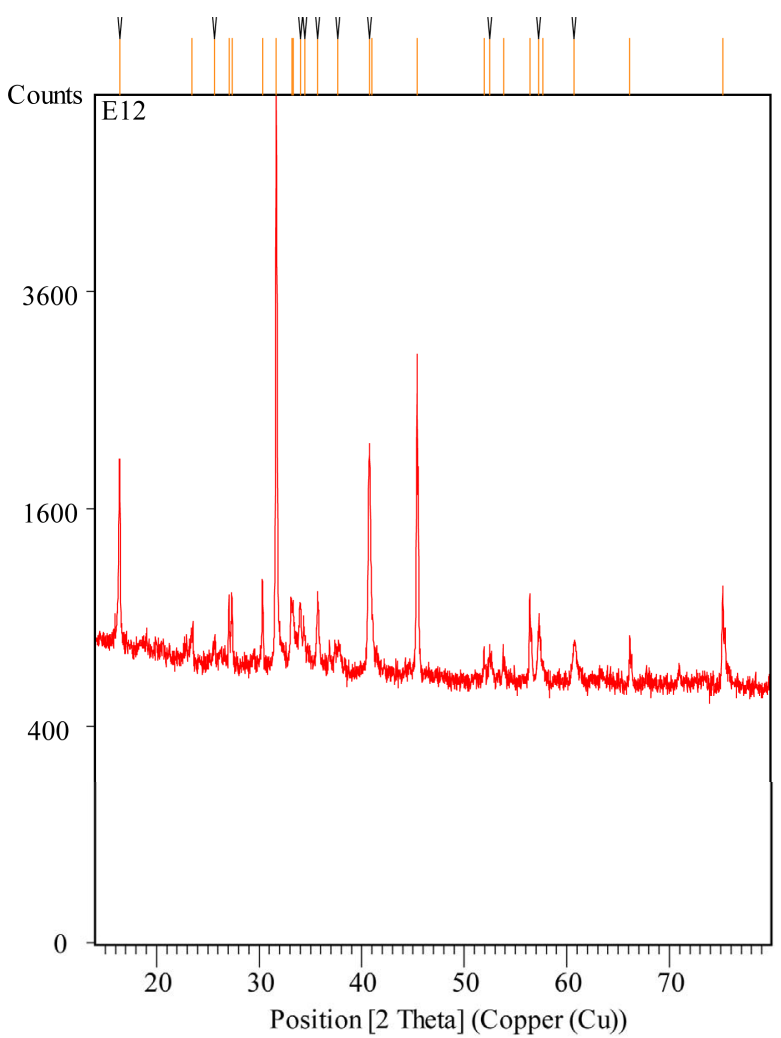

Figure 5. X-ray diffractometer of $\mathrm{Na}_{2} \mathrm{FeO}_{4}$. (elongation of the tetrahedron) have led W. Griffith [19] to consider a lower symmetry in $2 \mathrm{~d}$, very close to $2 \mathrm{~s}$ the $\mathrm{FeO}_{4}^{2-}$ anion.

IR spectroscopy is a quantitative method for the determination of iron(VI) compounds in the ferrate. The shape of the spectra is related to the symmetry of the molecule or $\mathrm{FeO}_{4}^{2-}$ groups (tetrahedral structure) the IR spectrum of $\mathrm{Na}_{2} \mathrm{FeO}_{4}$. Figure 6 showed a similar pace in the field of high frequency to similar that obtained (mode $825 \mathrm{~cm}^{-1}$ and $780 \mathrm{~cm}^{-1}$ ) by P. Tarte and G. Nizete [20].

The IR results support those obtained by XRD.

\subsubsection{ATG Spectrum}

In general, two stages of decomposition were obtained in the TGA curve up to $500^{\circ} \mathrm{C}$ Figure 7. A first one above $100^{\circ} \mathrm{C}$ corresponding to the evolution of water weakly adsorbed by the sample and a second step between $210^{\circ} \mathrm{C}$ and $310^{\circ} \mathrm{C}$ corresponding to the release of $\mathrm{O}_{2}$ Scholder et al. [21] and [22].

The two stages of decomposition were accompanied by endothermic heat effects as measured by TGA.

\section{Tracking the Degradation of Ferrates as Function of Time}

\section{Analysis by Mössbauer Spectroscopy}

The Mössbauer effect highlights the absorption of apho-

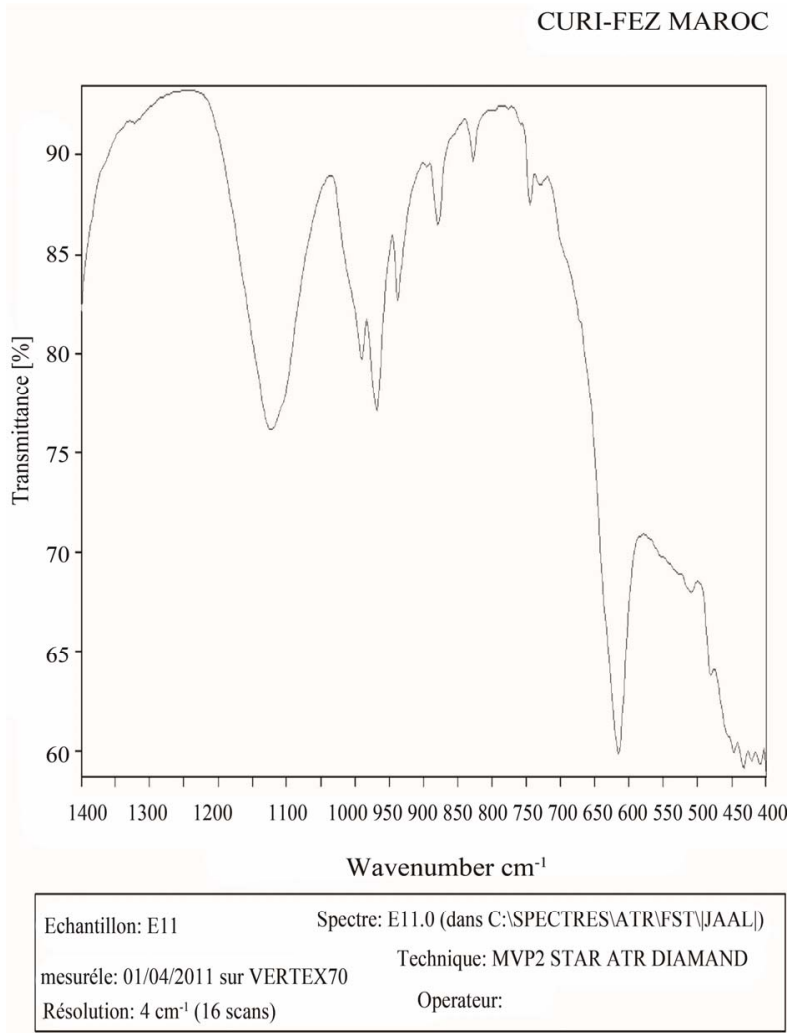

Figure 6. $\mathrm{Na}_{2} \mathrm{FeO}_{4}$ infra-red spectrometer. 


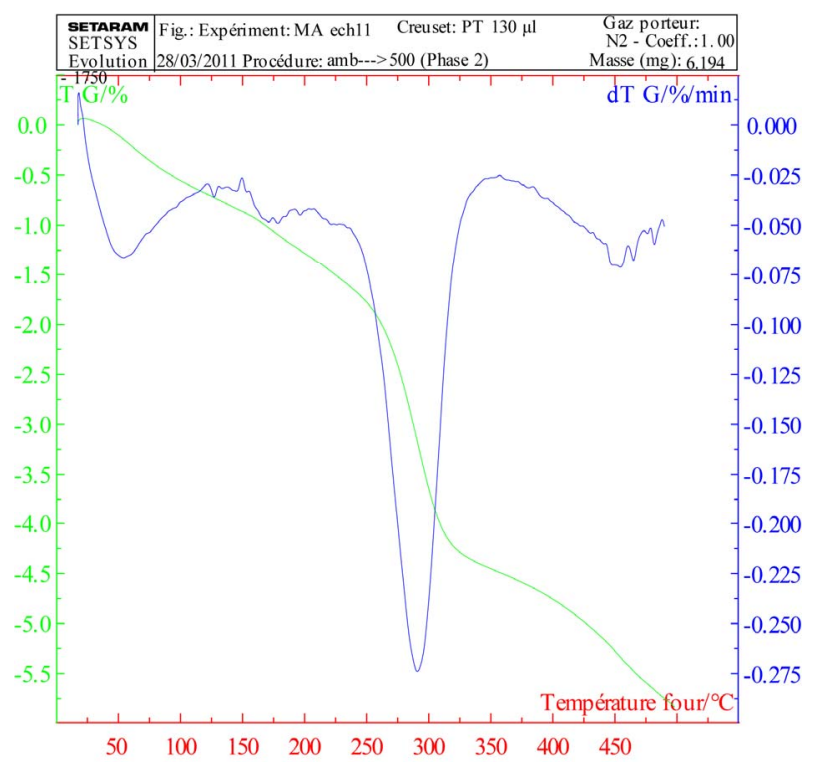

Figure 7. TGA spectrum of $\mathrm{Na}_{2} \mathrm{FeO}_{4}$.

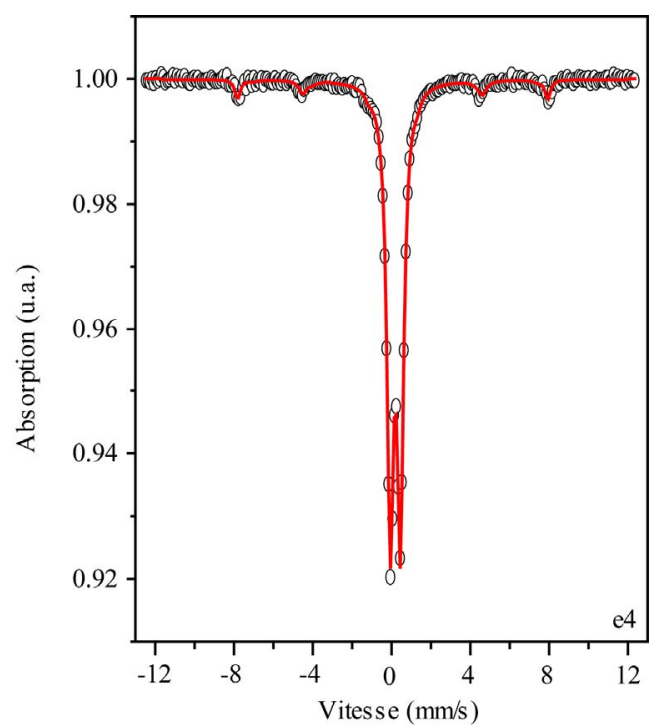

Figure 8. Mössbauer $\mathrm{Na}_{2} \mathrm{FeO}_{4}$ spectrometer after ten months of storage.

Table 1. Hyperfine parameters deduced from the calculation of the spectrum after ten months of storage.

\begin{tabular}{|c|c|c|c|c|c|c|c|c|c|}
\hline \multicolumn{10}{|c|}{$\mathrm{H}_{\text {hyp }}=$ hyperfine field, $\mathrm{A}=$ component weight in $\%$ of total spectrum } \\
\hline & \multicolumn{6}{|c|}{ Broadened component } & \multirow{2}{*}{\multicolumn{3}{|c|}{$\begin{array}{c}\text { Paramagnetic component } \\
\text { Doublet }\end{array}$}} \\
\hline & \multicolumn{3}{|c|}{ Sextuplet 1} & \multicolumn{3}{|c|}{ Sextuplet 2} & & & \\
\hline & $\mathrm{H}_{\text {hyp }}(\mathrm{kOe})$ & $\mathrm{ISO}(\mathrm{mm} / \mathrm{s})$ & $\mathrm{A}(\%)$ & $\mathrm{H}_{\text {hyp }}(\mathrm{kOe})$ & ISO $(\mathrm{mm} / \mathrm{s})$ & $A(\%)$ & $\Delta \mathrm{EQ}(\mathrm{kOe})$ & $\mathrm{ISO}(\mathrm{mm} / \mathrm{s})$ & A $(\%)$ \\
\hline E4 & 490 & 0.22 & 7.5 & 449 & 0.34 & 1.6 & 0.512 & 0.35 & 90.7 \\
\hline
\end{tabular}

ton $\mathrm{Y}$ by a nucleus of ${ }^{57} \mathrm{Fe}$ (present at a rate of about 2.6 percent in the natural iron): we varied gradually the energy of the photon emitted by variation of the speed of the source $\left({ }^{57} \mathrm{Co}\right.$. When it reaches a value equal to the difference between the energy level of the core in its ground state $(1=1 / 2)$ and its level in the excited state $(1=$ $3 / 2$ ) the photon is absorbed. This phenomenon results in a peak on the spectrum.

Mössbauer spectroscopy also helped to highlight the existence of a magnetic order at low temperature [23-27]. $\mathrm{Na}_{2} \mathrm{FeO}_{4}$ characterization by Mössbauer spectroscopy, after ten months of storage at room temperature, reveals a degradation of iron(VI) over time according to the Mössbauer spectrum Figure 8. We have a broad magnetic component calculated by the superposition of two sextuplets and a paramagnetic component adjusted by a paramagnetic doublet. The hyperfine parameters deduced from the calculation of the spectrum are given in Table 1.

This allows us to visualize the oxidation of iron and therefore control the rate of iron(VI) over time. This degradation is manifested on the spectrum by the isomer shift of the peaks to $0.22 \mathrm{~mm} / \mathrm{s}$ for sextuplets 1 and 0.34 for sextuplets 2 (see Table 1) while the sextuplet iron(VI) comes close to -1 [23-27].
This isomer shift is due to degradation of $\mathrm{Fe}(\mathrm{VI})$ to iron(III) because of moisture.

\section{Conclusions}

From the results, it's possible to synthesize at room stable sodium ferrate $\mathrm{Na}_{2} \mathrm{FeO}_{4}$ electrochemically at a temperature of $61^{\circ} \mathrm{C}$ and a current density of $\mathrm{I}=1.4 \mathrm{~A} / \mathrm{dm}^{2}$ in an alkaline medium saturated $\mathrm{NaOH}$.

Infrared spectroscopy shows that we are dealing with a compound containing the $\mathrm{FeO}_{4}^{2-}$ group.

Mössbauer spectroscopy of iron allowed us to visualize the oxidation of iron and therefore to control the rate of iron(VI), and track its degradation in iron(III) over time.

The XR spectrum of $\mathrm{Na}_{2} \mathrm{FeO}_{4}$ is isomorphic to that given by $\mathrm{K}_{2} \mathrm{FeO}_{4}$ literature.

The spectrum shows a peak ATG at $100^{\circ} \mathrm{C}$ corresponding to the release of water and a peak at $295^{\circ} \mathrm{C}$ corresponding to the decomposition of $\mathrm{Na}_{2} \mathrm{FeO}_{4}$.

\section{REFERENCES}

[1] B. Von Helferich, K. lang, Zeit. Anorg. Chem. Vol. 263, 1950, p. 169.

[2] R. J. Audette and J. W. Quail, "Potassium, Rubidium, Ce- 
sium, and Barium Ferrates(VI). Preparations, Infrared Spectra, and Magnetic Susceptibilities," Inorganic Chemistry, Vol. 11, No. 8, 1972, p. 1904. doi:10.1021/ic50114a034

[3] E. F. Fremy, "Recherches sur les Acides Mètalliques," Annales de Chimie et de Physique, 1844, pp. 361-382.

[4] W. Foster, "The Action of Alkaline Hypobromite on Oxamide, Urea and Potassuim Ferrocyanide," Journal of Chemical Society, Vol. 35, 1879, pp. 119-124. doi:10.1039/ct8793500119

[5] Blattner, "Action des Oxydes Mètalliques sur les Hypochlorites a Lcalino-Terreux," Bulletin de la Société Chimique, Vol. 7, 1892, pp. 700-708.

[6] M. Muspratt and S. Smith, "Some Experiments upon High Strength Hypochlorite Solutions," Journal of the Society of Chemical Industry, Vol. 17, 1898, pp. 1096-1100.

[7] W. F. Wagner, J. R. Gump and E. N. Hurt, "Factors Affecting Stability of Aqueous Potassium Ferrate(VI) Solutions," Analytical Chemistry, Vol. 24, No. 9, 1952, pp. 1497-1498. doi:10.1021/ac60069a037

[8] J. C. Poggendorf, Pogg. Ann, Vol. 54, 1841, p. 161.

[9] G. Grube and H. Gmelin, "Der Einfluss Überlagerten Wechselstromes auf die Anodische Ferratbildung," Zeitschrift für Elektrochemie und Angewandte Physikalische Chemie, Vol. 26, 1920, p. 153.

[10] G. Grube, "Die Passivitat der Metalle bei Anodischer Polarisation," Zeitschrift für Elektrochemie und Angewandte Physikalische Chemie, Vol. 33, No. 9, 1927, p. 389.

[11] B. Helferich and K. Lang, "Über Salze der Eisensäure Mit 3 Abbildungen," Zeitschrift für Anorganische und Allgemeine Chemie, Vol. 263, No. 4, 1950, pp. 169-174. doi:10.1002/zaac.19502630404

[12] H. Von Krebs, "Über die Struktur des Kaliumferrats und des Bariumferrats Mit 2 Abbildungen," Zeitschrift für Anorganische und Allgemeine Chemie, Vol. 263, No. 4, 1950, pp. 175-176. doi:10.1002/zaac.19502630405

[13] S. Licht, V. Naschitz, L. Halperin , N. Halperin, L. Lin, J. Chen, S. Ghosh and B. Liu, "Analysis of Ferrate(VI) Compounds and Super-Iron Fe(VI) Battery Cathodes: FTIR, ICP, Titrimetric, XRD, UV/VIS, and Electrochemical Characterization," Journal of Power Sources, Vol. 101, No. 2, 2001, pp. 167-176. doi:10.1016/S0378-7753(01)00786-8

[14] Y. L. Wang, S. H. Ye, Y. Y. Wang, J. S. Cao and F. Wu, "Structural and Electrochemical Properties of a $\mathrm{K}_{2} \mathrm{FeO}_{4}$ Cathode for Rechargeable Li Ion Batteries," Electrochimica Acta, Vol. 54, No. 16, 2009, pp. 4131-4135. doi:10.1016/j.electacta.2009.02.053

[15] W. C. He, J. M. Wang, H. B. Shao, J. Q. Zhang and C.-N. Cao, "Novel KOH Electrolyte for One-Step Electrochemical Synthesis of High Purity Solid $\mathrm{K}_{2} \mathrm{FeO}_{4}$ : Comparison with $\mathrm{NaOH}$," Electrochemistry Communications, Vol.
7, No. 6, 2005, pp. 607-611. doi:10.1016/j.elecom.2005.04.011

[16] R. J. Audette and J. W. Quail, "Potassium, Rubidium, Cesium, and Barium Ferrates(VI). Preparations, Infrared Spectra, and Magnetic Susceptibilities," Inorganic Chemistry, Vol. 11, No. 8, 1972, pp. 1904-1908.

[17] N. Becarud, C. Duval. C. R. Acad. Sci, Vol. 257, 1963, p. 1930.

[18] F. Gonzalesvilchez and W. Griffith, "Transition-Metal TetraOxo-Complexes and Their Vibrational Spectra," Journal of Chemistry Society, Dalton Transactions, No. 13, 1972, pp. 1416-1421. doi:10.1039/dt9720001416

[19] W. Griffith, "Infrared Spectra of Tetrahedral Oxyanions of the Transition Metals," Journal of the Chemical Society A: Inorganic, Physical, Theoretical, 1966, pp. $1467-$ 1468. doi:10.1039/j19660001467

[20] P. Tarte and G. Nizet, "Etude Infra-Rouge de Quelques Composés du Type $\mathrm{K}_{2} \mathrm{SO}_{4}$ et $\mathrm{BaSO}_{4}$," Spectrochimica Acta, Vol. 20, No. 3, 1964, pp. 503-513. doi:10.1016/0371-1951(64)80045-X

[21] R. Scholder, H. Bunsen, F. Kin, W. Zeiss and Z. Anorg, "Zur Kenntnis der Ferrate(VI)," Zeitschrift für Anorganische und Allgemeine Chemie, Vol. 282, No. 1-6, 1955, pp. 268-279. doi:10.1002/zaac.19552820129

[22] R. Scholder, "Recent Investigation on Oxometallates and Double Oxides," Angewandte Chemie, Vol. 1, No. 4, 1962, pp. 220-224. doi:10.1002/anie.196202202

[23] A. Ito and K. Ono, "Mössbauer Study of $\mathrm{Fe}^{6+}$ in Potassium Ferrate, $\mathrm{K}_{2} \mathrm{FeO}_{4}$," Journal of the Physical Society of Japan, Vol. 26, 1969, p. 1548. doi:10.1143/JPSJ.26.1548

[24] T.Shinjo, T. Ichida and T. Takada, "Internal Magnetic Field at Fe in ${ }^{57}$ Hexavalent States," Journal of the Physical Society of Japan, Vol. 26, 1969, p. 1547. doi:10.1143/JPSJ.26.1547

[25] T. Shinjo, T. Ichida and T. Takada, " $\mathrm{Fe}^{57}$ Mössbauer Effect and Magnetic Susceptibility of Hexavalent Iron Compounds; $\mathrm{K}_{2} \mathrm{FeO}_{4}, \mathrm{SrFeO}_{4}$ and $\mathrm{BaFeO}_{4}$," Journal of Physical Society of Japan, Vol. 29, No. 1, 1970, pp. 111116. doi:10.1143/JPSJ.29.111

[26] G. Hoy and M. Corson, "Critical Slowing Down of Spin Fluctuations in $\mathrm{K}_{2} \mathrm{FeO}_{4}$," Journal of Magnetism and Magnetic Materials, Vol. 15, No. 18, 1980, pp. 627-628. doi:10.1016/0304-8853(80)90693-9

[27] F. Menil, "Systematic Trends of the ${ }^{57} \mathrm{Fe}$ Mössbauer Isomer Shifts in $\left(\mathrm{FeO}_{\mathrm{n}}\right)$ and $\left(\mathrm{FeF}_{\mathrm{n}}\right)$ Polyhedra. Evidence of a New Correlation between the Isomer Shift and the Inductive Effect of the Competing Bond T-X $(\rightarrow \mathrm{Fe}$ ) (Where $\mathrm{X}$ Is $\mathrm{O}$ or $\mathrm{F}$ and $\mathrm{T}$ Any Element with a Formal Positive Charge)," Journal of Physics and Chemistry of Solids, Vol. 46, No. 7, 1985, pp. 763-789. doi:10.1016/0022-3697(85)90001-0 